\title{
Soma, an Enigmatic, Mysterious Plant of the Vedic Āryas: An Appraisal
}

\author{
N C Shah*
}

(Received 22 December 2014)

\begin{abstract}
Soma plant has been a mystery since a long time. A number of plants were proposed as Soma in the past by various authorities. Wasson (1968) proposed and claimed with a specific approach that Amanita muscaria, a mushroom was the Soma of the Rgveda. The juice of it was used as Soma drink. The Vedic Āryas (earlier called 'Vedic Āryans'), were the composer of Rgveda. They used to compose hymns (mantras) to record their day to day experiences, their cultural life and adoration of their deities including Soma. It is speculated, when, Soma became rare and was difficult to find, then Syena, the Falcon (a kind of bird) was used to collect and bring to their masters and it is well recorded in the Rgvedic hymns. Perhaps, Wasson did not give any importance to this fact, which actually well supports his findings.

Nothing is known about the origin or migration of Vedic Āryas. They used ephedra, cannabis and poppy in preparation of Soma drink and is supported by an archaeological finding by Sarianidi, in 2003 AD. Sarianidi called the Vedic Āryas as Zorastrians settled in Bactria and India. It is not certain what ingredients were used to prepare the Soma drink. In India, when they were in the mountainous region of Afghanistan and Kashmir, they used ephedra, which was plentifully available for preparation of Soma drink. With their work as they migrated in the Indian plains eastwards and southwards they had to use other locally growing plants as substitute or surrogates like: Sarcostemma spp., Ceropegia spp., Periploca aphylla, etc. because ephedra was not available.

The paper deals with the story as to how Wasson came to the conclusion that Amanita muscaria is the Soma of the Rgveda and the plants used as Soma in different periods of time with the movements of the Vedic Āryas. Lastly, the present status of Soma in Indian religion \& culture is briefly discussed, where it is worshipped and only mentioned in the hand books of daily worship used by the Hindu brāhmins (priests).
\end{abstract}

Key words: Amanita muscaria, Cannabis sativa, Ceropegia sp., Ephedra sp., Falcons, IndoĀryas, Indo-Iranians, Madhuca indica, Margiana, Nelumbo speciosum, Nymphaea sp., Papaver sp., Peganum harmala, Poppy, Ruta graveolens, Sarcostemma brevistigma, Vedic-Āryas.

\section{INTRODUCTION}

Soma was stated in Veda to be a divine and sacred plant, with its miraculous properties, which enlightened the worshipper and the person who drank its juice. It played an important role in the cultural life of the Vedic Āryas (earlier called 'Vedic Āryans') as a cult. It is stated that the hunt for Soma plant in India began in 1784 (230 yrs ago), when the first English version of ' $S$ r $\bar{\imath}$ Bhagvadgìt $\bar{a}$ ' reached Europe. The westerners, for the first time knew about this divine plant and they were much eager to know more about it and to procure it. But, no plant under the name of 'Soma' was in use. A botanical hunt for the plant was then

\footnotetext{
* President, Society of Ethnobotanist (India), Founder \& Ex. Director, Herbal Research and Development Institute, Uttarakhand \& Retd. Head Botany \& Pharmacognosy Division, CIMAP (CSIR) \& Founder Secretary cum Treasurer of Society of Ethnobotanist MS-78, Sector-D, Aliganj, Lucknow-226024. E-mail: shahncdr@gmail.com
} 
undertaken by the European botanists, vedists and theologists, and others, working at that time, in India. However, Hillebrandt, (1891) and MonnierWilliams (1899) were the first vedists to probe into the Soma and the drink prepared from it.

However, a number of plants were proposed as Soma by various authorities in due course of time such as; Ruta graveolens, Roxburgh (1814), Sarcostemma brevistigma, Roxburgh (1820-24), Ephedra sp., John Stevenson (1842), and others. which, are well documented in chronological order by Shah \& Badola (1977) and Shah (2011). There were many speculations and theories when, Wasson (1968) published his findings that a mushroom, Amanita muscaria is the Soma of Rgveda then a number of foreign and Indian workers began to give their comments and views in favour and against his findings. The main works to be cited are: Sharma (1969); Brough (1971); Ingalls (1971); Shah (1973); Yajnik (1973); Madanmohan (1975); Mahdihassan (1986, 1991); Sharma (1996); Padhy et al. (2001); Padhy \& Dash (2004); Nene (2004); Nene \& Putoo (2004); Nene \& Shadhale ( 2004); Swami (2010) etc.

These publications have not at all changed the findings of Wasson that Amanita muscaria, is Soma of the Rgveda or the Vedic-Āryas. The historical identity of the Vedic Āryas has been defined by Talageri (2000, p.72.): “According to the scholars, the Vedic Āryas were (later) a branch of the Indo-Iranians, one branch of these IndoIranians, the Indo-Aryans, migrated southeastwards into the northwestern parts of India; and thus commenced the story of the Āryas in India.” The Vedic Āryas originally used the 'flyagaric' mushroom, and composed Rgvedic hymns (mantras). And, when, 'fly-agaric' had depleted and was not readily available then, supposedly, they used Falcon (Śeyna) bird to collect it and bring it to their masters. When, they left their original homes and moved away, they used ephedra, cannabis and poppy to prepare Soma drink. Later on the cannabis and opium was not available to them.

Lastly, when they moved and settled down in India in the Sindh plains and Indo Gangetic plains, they had to use the substitutes and surrogates like; Sarcostemma brevistigma,, Periploca aphylla, Ceropegia sp., and other plants having similar properties. The article deals with Soma and related issues along with Wasson's approach, findings and the history behind it.

\section{VEDIC ĀRYAS}

\subsection{Rgveda and the Vedic Āryas in their original home}

According to Wasson, (1968), there were number of tribes in Central Asia and many such tribes are still living within this region and using a mushroom, the 'fly-agaric' Amanita muscaria for preparing a invigorating drink.

By about 5000 B C an intelligent group of a nomadic tribe, out of many had begun to memorize their feelings, observations of nature, experiences of life and environment, in divine revelation in form of hymns (mantras). They also began to record their important geographical identities, historical events, incidents, and their philosophical thoughts, and the deities to whom they adored and venerated especially, the plant, Soma, with a cult. They performed their specific religious rites, known as 'Homa'. These oral well memorized poetic hymns were later known as "śruti" (Kak, 1987, p.232 \& Nene \& Sadhale, 1997, p. 177). Later on, these oral hymns were transcribed in a newly created language known as the Archaic (Prakrit) Sanskrit and later to the present day Sanskrit.

\subsection{Rgvedic information}

Rgveda as such, contains a veritable treasure of information, which sheds light on the 
early history of the Vedic Āryas as a whole. The hymns are full of textual purity, which throw light on the religious and spiritual life of the people. Not only this, they also composed hymns on the worship and adoration of the plant Soma, which they had used to make an invigorating drink used in certain ceremonial occasions. According to Wasson (1972, p. 14) “The Vedic hymns marked a high point in the religious life of the Ârya people, in which the rapturous experience produced by Soma led the Brāhamans to clothe the celebration of the sacrament in an amazing ritual, perhaps without parallel in history."

In Rgveda, which consist of 10 Mandala or books, the total number of hymns are 10,552 , out of which 1028 verses are on Soma. The IX Mandala (Book) is well saturated with Soma description and there are total 114 hymns on Soma.

\subsection{The Settlement of the nomadic Āryas or the Vedic Āryas}

Before 2500 BC, the advanced VedicĀryas possibly, migrated from Central Asia towards South-West in Karakum desert in Turkmenistan by the side of the Murghab river. The same nearby locations have also been mentioned and shown in the maps as Nagalok (Shastri 1977, p. 67, .68, 170), Harivarsha (Shastri 1977, p.68), Uttarkura (Shastri 1977, p. 70).

This fact came to be known from an archaeological excavation at Gonur Tepe site, dating back to 2500 BC by a Greek-Russian archaeologist (Sarianidi, 2003). The cause of the migration from their original home is not understood. Possibly, it could either have been the depletion of the Soma plant, in their native place or they wanted to settle and leave their nomadic life, is not clear.

\section{3. Āryas and Archeology}

The Greek-Russian archaeologist Sarianidi (2003) for the first time, found a palace, of about the size of a football field, a fortified mudbrick enclosure, and a massive shrine, the Āryas temples with fire altars (havan kunda), in which remains of 'Sacrificed' horses were also found (Aśvamedh yajña). And, for the first time, the remains of chariot with horses were also recovered. Not only this, big vessels were uncovered, in which Soma drink were kept. A pounding-hole was also found in which the ingredients of Soma drink were pounded. A big boiler was also found in which, the ritual drink Soma, was prepared. According to Prof Sarianidi, the remains of the ingredients were the ephedra, cannabis and poppy, which were used for preparing the Soma-Homa drinks. Ephedra was found in form of ephedrine alkaloids and poppy was found in form of seeds, Further, thickets of these plants were also found in abundance in the vicinity of the excavated temples of Margiana, suggestive that they had also cultivated these plants. According to Sarianidi (2003), the ingredients of Soma have been revealed for the first time. This fact came to be known from an archaeological excavation at Gonur Tepe, site, dating back to 2500 BC.

According to Sarianidi (2003), Gonour Tape was the culture but a lost civilization. This archaeological evidence was not only for the first time for the Soma (substitute) remains but also confirmed the theory that the Āryas had some connection with Central Asia.

After their migration to Bactria in north of Afghanistan, they continued composing and chanting their hymns which were well memorized and these were later known as 'śruti'. The religious tradition of Soma worship was called 'hoama' by the Parsis. One group moved towards India crossing the Hindukush Mountain in the Himalayas and reached Sindh. At that time, Indus civilization of Mohenjo-Daro was in existence and possibly they fought with them and pushed them away towards south. First, they settled down by the side of the river Indus, which they called as 
Sindh and then, simultaneously, they moved towards east to the Ganga-Jumna plains to give rise to what is now called the Hindu religion.

\section{SOMA IN RGVEDA}

\subsection{The Soma of $\operatorname{Rgveda}$}

Amanita muscaria, the mushroom, was possibly used by the 'Vedic tribe'. According to Wasson (1971), the tribes were roaming and also composing and reciting the hymns, in adoration and praise of Soma and the drink prepared from it is hard to believe. Rgveda, is a unique and most complicated composition ever made in the history of human poetic literature but the hymns are not in chronological sequence, and up to now no one has been able to correlate and collate, the description of Soma with each other hymns chronologically (Talageri, 2000). Wasson, (1968, 1971) had however observed and described the morphology and characters of Amanita muscaria with the description of Soma, from the Rgvedic hymns and matched and collated it with beautiful coloured photographs.

\subsection{The Description of Soma in Rgveda}

The early references of Soma is found in all the Vedic literature with Rgveda, Yajurveda, Sāma-veda, and Atharva-veda and later in Brāhmanas. However, the first hymn of Soma is found in mandala I, in Rgveda. But it cannot be the first, in chronological order, as the hymns were composed in different periods of time by different $R$ śis and it is difficult to place the hymns in chronological order (Talageri, 2000). Talageri, (2000) has also made an effort to bring the hymns of $10^{\text {th }}$ mandala in their time of sequence.

However, the Ist hymn of Ist mandala (Book) on Soma is as under;

वायवा याहि दर्शतेमे सोमा अरंकृताः।

तेषां पाहि श्रुधी हवम।।

(ऋ.वे.मं.1अ1 सू. 2)
In this hymn prayer is made to 'Vāyu' that 'Soma is prepared for you and accept the same and listen to our prayer.

\section{Soma AND ITS IDENTIFICATION}

\subsection{Wasson and his identification of Soma plant of Rgveda}

A very few people know that R.G. Wasson, 1898-1986, was a Wall Street Banker and vice president of the J.P. Morgan Trust, and mycology was his past time job (Forte, 1997, p. 67). He continuously worked on ethno-mycology and hallucination properties of mushrooms, in Mexico with his wife, Valentina P. Wasson M.D., a pediatrician. After her death in 1958, and after his retirement in 1963, he continuously, worked alone in Central Asia, and had collected ethnobotanical information on the use of Amanita muscaria, the 'fly-agaric' mushroom from the Central Asian tribes, and, one day, on a casual discourse with his friend, Louis Renou, 1896-1966, an eminent, French Indologist and a Vedic scholar as how the tribes used the fly-agaric mushrooms. He described all the events such as how they collected and extracted the juice as a drink. He also showed him the photographs. Renou, at that time, was studying Rgveda and he suddenly said that Wasson was not speaking of the fly-agaric but of Soma of the Rgveda. Wasson for the first time, had heard about Soma and about Rgveda. After that he took help from Renou, in searching the description of Soma in the hymns of Rgveda and comparing and matching them with the fly-agaric, mushroom. The morphological features, colour, habit, etc. were matched and collated with the Sanskrit hymns translated by Louis Renou. As a result it was found that the hymns on Soma in Rgveda, had actually described the fly-agaric (Amanita muscaria).

As Wasson had many questions regarding Sanskrit words so he requested H.H. Ingalls, a leading Sanskrit scholar to recommend him a graduate student, who could help him with 
questions about Sanskrit. He recommended the name of Wendy Dongier O' Flaherty, who answered many questions marvelously, which Wasson wanted to know. It is strange to know that she was at Cambridge, Massachusetts and Wasson was at his home in New York, a long distance, and they were discoursing with each other efficiently. Later, Wendy Dongier O’ Flaherty did her Ph.D. in Sanskrit from University of Harvard and she went to Oxford from where she took another degree in Sanskrit Studies and then she became the Prof. of Sanskrit at University of Chicago (Forte, 1997, pp. 70, 71). Later, she had also contributed the IInd Chapter in the Wasson's book, "Soma: The Divine Mushroom of Immortality."

Before writing his book, Wasson pursued research on Soma and Rgveda and came to India four times. Thus his meticulous efforts and findings resulted in his famous book on Soma. His work is not based only on theoretical aspects but meticulously and critically into the historical and other scientific fields such as; mycology, ecology, ethnobotany, phytochemistry, pharmacology and toxicology, folklores art and poetry, and above all based on translations of the hymns of Rgveda by Louis Renou and as a result identifying Soma as the 'fly-agaric' (Amanita muscaria), a unique

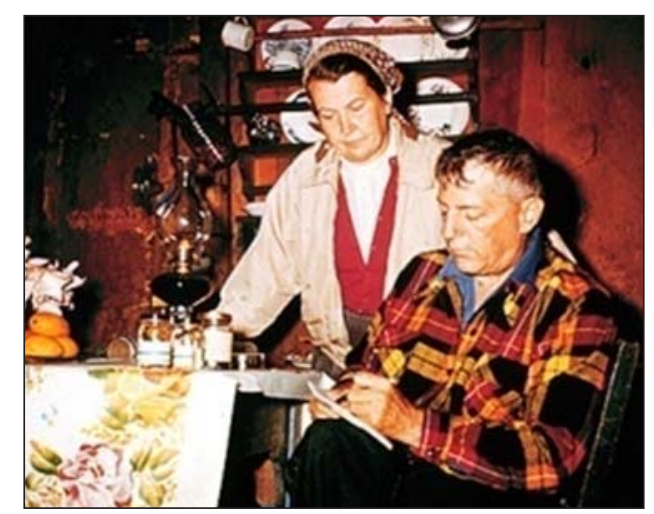

Fig. 1. Late Wasson and his wife Late Valentina P. Wasson M.D. worked together on mushrooms and in ethnomycology in Mexico.(Photo by Courtsey The Librarian, New York Botanical Garden, New York) endeavored effort yet ever to be undertaken and witnessed.

\subsection{Wasson's identification of Soma plant of Rgveda}

According to Wasson (1968 and 1971) the Soma plant as described in Rgveda had no leaves no flowers or its blossoms, no fruit, seed, no roots. etc. There are many references to its stem ' $a m s u$ ' and to its cap 'murdhan' or 'siris'. Further, the plant grew on the mountains and was red, its unmixed juice was yellow or brown. In several Vedic metaphors, compared with the sun and fire, it has been called, the 'naval of truth' 'nābhi'; and its stipe, is the stem or 'amsu' or 'the pillar of the sky', 'ek pād' or single footed.

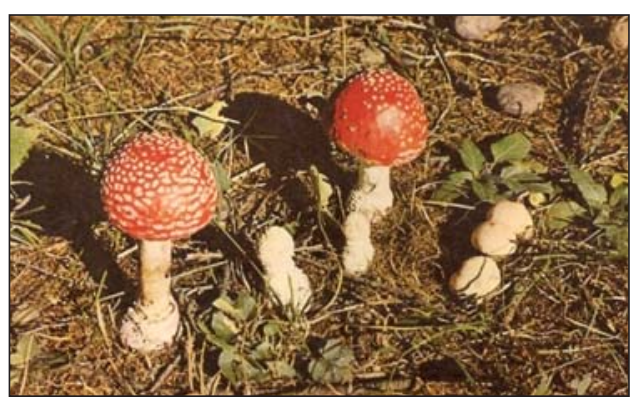

Fig. 2. Soma plants growing in natural habitat in different stages of growth.

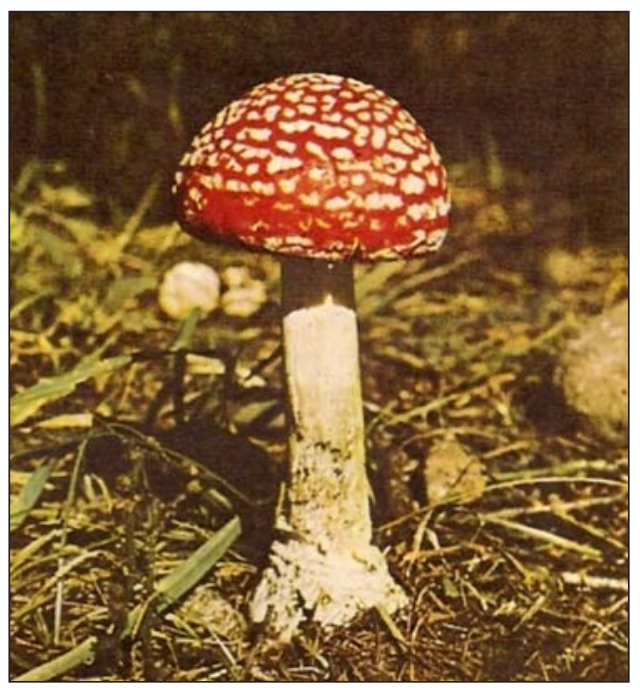

Fig. 3. Soma plant as 'Pillar of the sky' or "Mainstay of the sky' and as 'Ek pād' single footed.(See hymn ऋ.वे. मं.1अ1 सू. 2). 
When ripe, it has a fiery red cap and when it first appears, it is a fluffy ball dazzling and white as sun; when, it swells, it grows upward, it bursts into a white envelop and is brilliant like red fire.

It resembles, the Rgvedic swollen udder, in day, it appears, 'hari' (dazzling) and by night it becomes 'silvery white' as per Rgvedic description. All these descriptions have been beautifully illustrated through colored photographs by Wasson (1968, 1971). Not only this, the 'fly- agaric' juice description in Rgveda has also been well illustrated by a photograph. A number of points raised on the above issues and other issues have been well answered by Wasson, (1972) in his rejoinder.

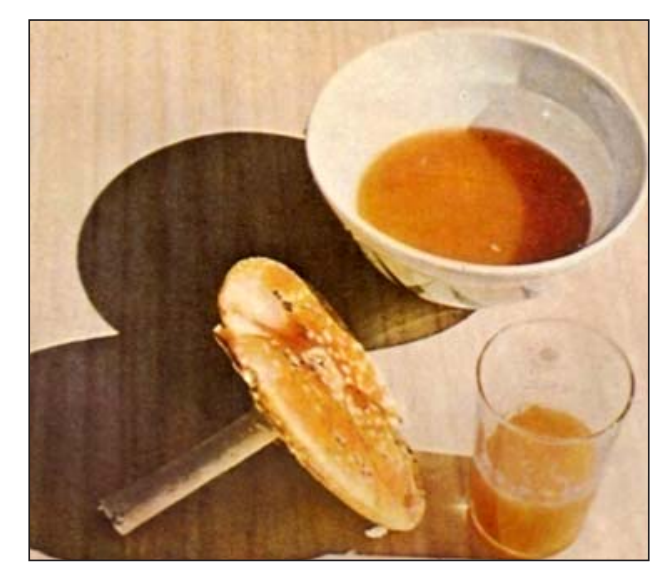

Fig. 4. Soma juice extracted by Wasson from Amanita muscaria as 'Soma' or 'Soma-ras' of Vedic Āryas living in Central Asia

The most objectionable theory which Wasson proposed in his thesis on Soma was the Third Filter. In this he explained that the Siberian tribesmen not only chew the fly-agaric they occasionally drink the urine of himself or someone, who has eaten the fly-agaric. This practice still remains in Siberia and Wasson tried to correlate it with some of the hymns of Rgveda. Most of the scholars of Sanskrit, Ingalls (1971) and Brough (1983) have out rightly rejected this evidence. However, Wasson's work suggests new ways of looking at Rgveda and other Vedas and new roads of enquiry into the meaning, has been set in.

\subsection{Wasson's visit to India}

Wasson while undertaking the research on Soma had spent several years, in the countries like Japan, China, and in European University centers and libraries, where most of the literature on VedicSoma was available. He also visited India in the years 1963 and 1965, 1966 and 1967 consequently. He visited Ranchi and the caves of Bagh (Madhya Pradesh) to search whether there were any sketches drawn by the cave dwellers on the walls of any mushroom and to find whether, Amanita muscaria, is distributed in India or not? (Dr.M.M.Payak Mycologist in 'Dharmayug' 26.10.1975 in Letter to the editor). Manilal (1980, pp. 321, 322) had reported that there are megalithic lateritic monuments in form of large mushroom, reported from different locations from Kerala and efforts were made to correlate these with Psilocybe and Amanita, mushrooms or with the Soma of Wasson. It was further reported that Amanita muscaria has been found in Tamil Nadu especially from the Nilgiri Hills in the southern India (Wasson \& O’Flaherty, 1982, p. 601).

This statement is doubtful and further requires re-survey of the region. It is well known that Amanita muscaria always grows under Birch trees, which acts as a host, and the birch trees do not grow in Nilgiries, in South India. Yes, it is reported that some other species of Amanita is found in South India.

It is to point out that Amanita muscaria is also not found in Kashmir of (British India) as there are no confirm reports of its occurrence. Though, in Afghanistan it has been well reported to occur, Wasson \& O’Flaherty (1982, p. 601) quoting Afghanistan Journal (6:2;979).

\subsection{Comments on Wasson's Soma plant}

When his book was published, a number of reviews, both favorable and critical, were 
published in a number of journals. According to Smith (2001, p. 13), eighteen reviews of his book were published in different journals of the world and seventeen validated his conclusion. The most lengthy review entitled "Wasson's Soma" appeared in The Journal of the American Academy of Religion (Smith, 2001, p. 13) . Only one very important critical review came out in the 'Bulletin of the School of Oriental \& African Studies' (BSOAS), published from University of London by Boroughs, a professor of Sanskrit in University of Cambridge. He out rightly rejected Wasson's findings that Amanita muscaria, a mushroom, is the Soma of the Rgveda (Wasson-Rejoinder, 1972).

Wasson wanted to reply on the comments of the review, in form of a rejoinder, and sent his reply to "BSOAS" but they out rightly refused to publish it, stating that they do not publish any rejoinders of the book-reviews. Then, Wasson sought their permission to publish the rejoinder in some other journal, and again they straight away declined.

Then, Wasson at the suggestion of Richard Evans Schultes, Professor of Botany \& Director of the Botanical Museum privately published, a 58 pages rejoinder under the title, 'Soma and the 'fly-agaric' from the Botanical Museum of Harvard University, Cambridge with a Forward by Schultes, in 1972. In this publication, Wasson replied to Borough's comments one by one.

In this rejoinder there are many new facts, which were not present, in his book on Soma, (Wasson-Rejoinder 1972).( The author had also received a copy of the 'Rejoinder' from Wasson in exchange to his article published in 'Dharmayug' (1971) in Hindi).

\section{Soma collection by Śrena (Falcon)}

Presently, the hunting by Falcons is well known in number of Asian countries, like Mongolia, Tibet and Arabian countries,
Afghanistan, etc. Since time immemorial, the falcons are trained to capture small hunts like rabbits and other game-birds and after capturing they bring them to their masters. In similar way, during those days, these Falcons might have been trained and used to collect Soma the fly-agaric from the far away distances and from high mountains and bring them to their masters.

This is also to know that during that time, Soma was a valuable commodity and it was exchanged with the food, cows, horses and with the gold. However, Wasson had somehow missed the important hymns (references) of Śyena (Hawk) in the Rgveda which are available from $1^{\text {st }}$ mandala to $10^{\text {th }}$ mandala, and which narrates that the Soma plant was brought from the high mountains by the bird called Syena or Suparna (beautiful feather bird). Monnier Williams (1899, p. 109) has stated that Soma was brought from the sky by a Falcon (Śyena), guarded by Gandharva. Later, Mukhopadhayay (1923, p. 189), Chitampalli, (1975) and Talageri (2000), also mentioned about role of Falcons in collecting and bringing Soma to their masters.

Talageri, has cited about 20 hymns (Talageri, 2000, p.74) that Soma was brought by an eagle (Falcon) to their masters. 'or the Vedic people'. These are as follows: I.80.2,93.6; III.43.7; IV.18.13,26.4-7,27.3-4,38.2.; V.45.9; VI. 20.6, 46.13; VIII.82.9; 100.8., IX.68.6, 77.2, 86.24;87.6 and X.11.4,99.8,144.4-5.

However, two references for 'Śyena' have been cited by Chitampalli, (1975) and not cited by Talageri (2000), are as under;

$$
\begin{aligned}
& \text { आन्यं दिवो मातरिथ्वा जभारा। } \\
& \text { मश्नादन्यं परिश्येनो अद्रेः।। }
\end{aligned}
$$

(ऋ.वे.मं.1अ. 93सू.06)

अग्नि सोमा ब्रह्मणा वाव धानोरुं यज्ञाय चक्रथरू लोकम्। अतस्त्वा रयिमभि राजानं सुक्रतो दिवः सुपर्णो अव्यथिर्भरत् | |

$$
\text { ( ऋ.वे. मं.9 अ.48 सू.3) }
$$


Gist of the hymns: Soma has been brought by Śyena (Falcon) or by a bird Suparṇa to Indra; It is brought from the sky; and from far away distances, from the top of the mountains, from the lands of the enemies, etc. It is brought, where Varuna had placed it; It is brought by the daughter of the Sun from the place, where the Rain- God, Parã̃̃jaya, the father of Soma nourished it (the mushrooms always come up with the rains), when it was taken by the Gandharvas; Indra has brought it from the sky and from the mountains.

There is an important hymn in mandala IX,77,2, which states that an archer Krșna- - not a protector of Soma is ready to shoot the Falcon. It shows that Soma was so much guarded. At present, the Falcons, have now become rare and endangered and efforts are being made to protect these in states like Mizoram, Arunachal Pradesh and Nagaland (Adam Halliday, 2014, p. 8).

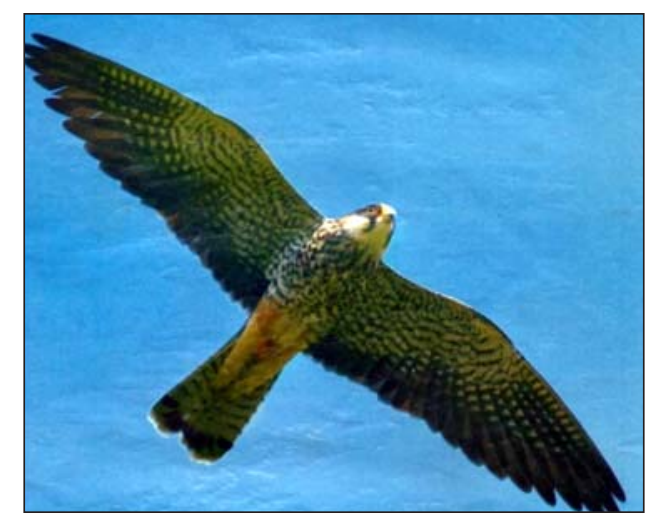

Fig. 5. Falco columbarius, the Falcon (Śyena of Rgveda) was used to collect Soma, the Fly-Agaric mushroom from far distances and bring to his master

\section{History of Soma AND THE Āryas}

The history of Soma plant is well associated with the history of the Âryas (the Vedic Āryas or the Indo-Āryas) and with the early Hindus of India. Different plants were used, when available, in different periods of times, and their uses have now completely forgotten and lost in the pages of history.

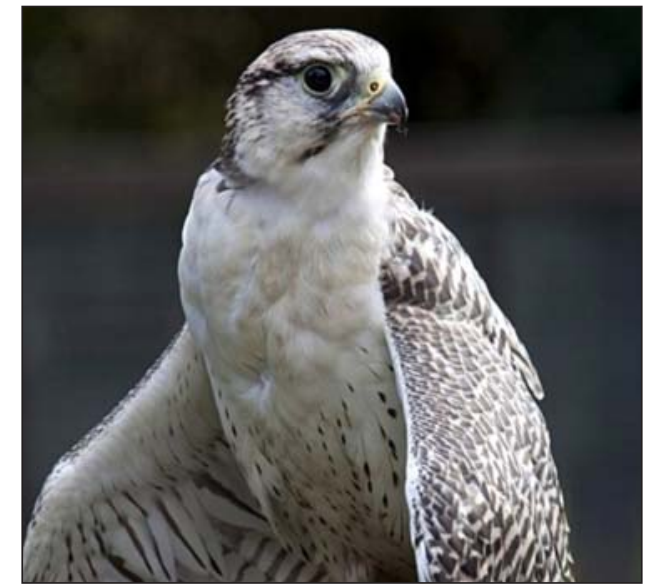

Fig. 6. Śyena or Suparna or Gāyatri names were used for Falcon, which collected Soma plant, when the āryas were in Central Asia

The finding of Sarianidi, (2003), clearly show that the Âryas had left the use of fly-agaric when they were at Margiana and were using ephedra, cannabis and opium to prepare the Soma drink. However, Wasson (1968, 1972 and 1983), was of opinion that the use of real Soma was left when they had reached the Indian plains, where Amanita muscaria was not available. This statement requires modification and correction. Possibly, this hymn was composed and used at Margiana, and not in Afghanistan or India, where they reached after 1000 yrs from Margiana and it is not possible due to a gap of such a long time. The hymn is as under which clarifies this fact:

$$
\begin{aligned}
& \text { सोमं मन्यते पपिवान यत् सपिंषन्तयोषधिम् । } \\
& \text { सोम यं ब्रह्माणो विदुर्न तस्याश्नाति कश्चन।। } \\
& \text { (ऋ.वे.मं. } 10 \text { अ. } 85 \text { सू } \\
& \text { The Soma which the Brāhmans (the } \\
& \text { priest) know, no other person knows and } \\
& \text { the people think that they have drunk } \\
& \text { Soma actually, they are not drinking the } \\
& \text { true Soma. }
\end{aligned}
$$$$
\text { (ऋ.वे.मं. } 10 \text { अ. } 85 \text { सू. 3) }
$$

Wilson (1925) translated it as follows: "Men think that they drink Soma, when the Soma plant is pressed but the true Soma as known to Brāhmins (priests) no one gets a drink.” Further in the 9.47.4 it is stated "O-Soma the priest conceal 
you. Hear the sound of stones but no one on earth gets you as drunk".

\section{The Beginning of the use OF OTHER PLANTS}

At Margiana, Amanita muscaria was not found, in its place were used ephedra, cannabis and opium in combination, as stated by Sarianidi (2003). What was the reason that the three psychoactive plants were used to prepare the Soma drink replacing Amanita muscaria is yet to be revealed. However, we would discuss in brief the chemistry and pharmacology of the plants, used to prepare the 'Soma-drink' starting with Amanita muscaria, ephedra, cannabis and poppy discussed below in brief:

\subsection{Amanita muscaria, the 'fly-agaric' as Soma}

In fresh or Sun-dried, Amantia muscaria Ibotenic acid, is present ranging from $0.03 \%$ to $0.1 \%$ and when it dries, the Ibotenic acid changes to muscimol which is five times more powerful than Ibotenic acid and pharmacologically both are intoxicating and hallucinogenic in action. Schultes (1963, p. 20) had very well defined hallucinogens as: "These act on the central nervous system to bring about a dream -like state marked by extreme alterations in consciousness of self, in the understanding of reality, in the sphere of experience, and usually by serious changes in perception of time and space; they almost invariably induce a series of visual hallucinations, often in kaleidoscopic movement, usually in rather indescribably brilliant and rich and unearthly colors, frequently accompanied by auditory and other hallucinations and a variety of synesthesias”. It is well mentioned in Rgvedic hymns that dried Soma was used, which was soaked in water and then it was pressed with fingers like the udders of the cows in milking and thus juice was extracted (Wasson 1968 and 1971).

The fly-agaric and cannabis both are hallucinogenic action.

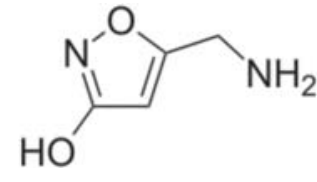

Muscimol

\subsection{Ephedra as a part of Soma drink}

Its principal active ingredient is ephedrine, which is like amphetamine-and adrenalin like compound that potentially has powerful stimulant effects on the nervous system and heart. Like an amphetamine, ephedra increases both blood pressure and heart rate, decreases appetite, and makes the user feel energetic and enhances concentration, it is why it was used by the Buddhist monks. Possibly, the herb was used, in preparation of 'Soma drink' as a general stimulant for alertness and energy and as an appetite suppressant, and to give concentration, at the times, when the Buddhist monks and preachers were required to travel far and long distances to promulgate Buddhism (Shah 2005, p. 30).<smiles>CN[C@H](C)[C@H](O)c1ccccc1</smiles>

\subsection{Cannabis as a part of Soma drink}

It is also a psychotomimetic or hallucinogenic drug, the main active constituent which effects the mind is Tetrahydrocannabinol (THC), which is the primary psychoactive component of the Cannabis plant.

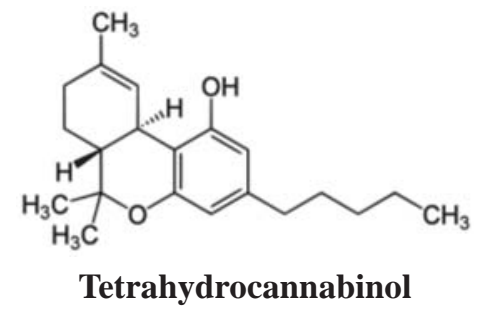

Seeing the use of Cannabis in many parts of India as a drink known as 'bhānig', Mukerjee 
(1921-22) advocated that Soma plant was Cannabis sativa. Many agreed with his statement as there is a custom of cold-bhäring drink sold in number of northern cities in India. The preparation is like the Soma drink which gives pleasure and well-being. It has further been seen that Cannabis is very useful herb which also reported as a narcotic and hallucinogenic in action (Grotenhermen and Russo 2002).

\subsection{Papaver sp. as a part of Soma drink}

At Margiana, Papaver species was used and which contains the main active chemical constituent Morphine and other alkaloids. Pharmacologically, the combined effect of all the alkaloids brings a feeling of euphoria or well-being followed by forgetfulness.

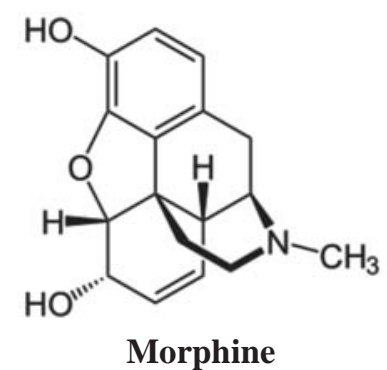

In general, the overall action of the above stated plants would have been as follows Amanita muscaria is a hallucinogenic in action; Ephedra is a powerful stimulant, decreases appetite, and makes the user feel energetic and enhances concentration; Cannabis is hallucinogenic and Poppy (Papaver sp) brings a feeling of euphoria or well-being followed by forgetfulness.

\section{EpHEdRa As Soma}

First of all, Stevenson, in 1842 identified Ephedra species (Ephederaceae) as Soma on the basis of plant being called as 'huma' or 'suma' and used in Afghanistan and Pakistan region, where it is still known under the above names (Shah 2011, p. 26). In Afghanistan, the decoction of the plant or tea of the plant is still used as an stimulant, and sold in every crude drug shop under the name 'Huma'. Later, a number of people also proposed Ephedra sp. as Soma. Earlier, Chopra, et al (Chopra 1958, p. 145), had considered Ephedra intermedia as Soma from which the favorite drink of the Rsis of the Vedic period in India was prepared but at that time, there was little evidence to support this statement, Later, Qazilvash, 1960 quoted by Mahdihasan (1963, p. $370,373)$, was working on ephedra in the field on the commercial extraction of ephedrine in Peshawar and where, ephedra was locally known as Soma, this supported the view that ephedra is Soma, in India. The most interesting evidence was given by Mahdihasan (1963, p. 370, 373) and he was able to support this view that ephedra is Soma based on an evidence of a sculpture, lodged at Peshawar Museum, in Pakistan. In this sculpture, it is shown that a tribal is offering a bundle of a plant twigs to Lord Budha and a heap of the offered plants and twigs is lying on the floor (See Fig. 7). The plant in the sculpture was identified with its the morphological characters as the Ephedra sp. (Mahdihasan p. 370, 371) .These two evidences were well enough to support that ephedra was Soma used in India. Further, in Peshawar region ephedra is found growing in wild condition and known as Soma or Suma.

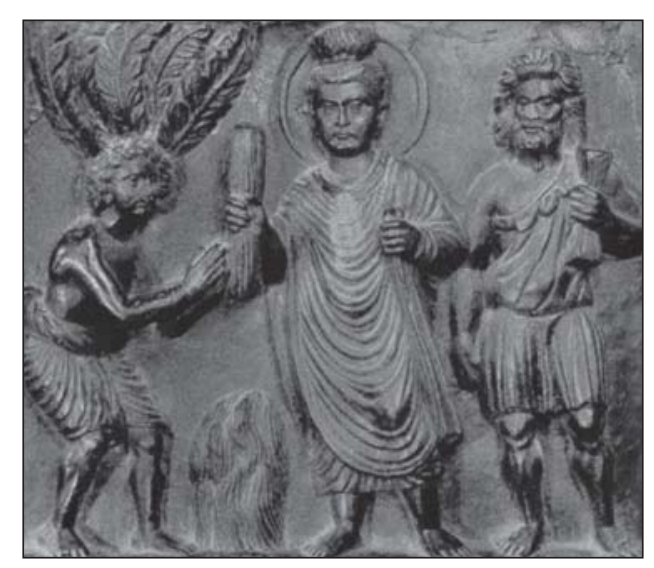

Fig. 7. The devotees of Buddha offering Ephedra sp., to Lord Buddha, identified from the sculpture by Mahadihasan of Pakistan. A Gandhar sculpture from Peshawar Museum (Pakistan). 
Earlier, Wasson (1968 and 1971) has mentioned that up to Hindukush and Afghanistan fly- agaric was available to the Indo Āryas but it is certain that they had not used because they had left its use about 1000 years ago and, it is difficult to believe that they had had used it again after such a long time gap. They had only used, Ephedra, in Afghanistan and India, and possibly also in Bactria, where they stayed for a short period and where Ephedra was plentifully available.

\section{Substitutes \& Surrogates of Soma}

According to Damania, (2001,2004,), the Vedic-Āryan began to use Peganum harmala, and Tamarix sp. in their first home Iran as Soma when Ephedra sp. was not available to them. Similarly, after reaching the Sindh plains in India, where ephedra was not available, they used plants like; Sarcostemma sp. Periploca aphylla, etc. in different periods of time and in different parts of the country. Sharma (1969, p. 384), after describing the qualities of Soma in Vedic literature also states about its substitutes and surrogates. He states, in case, when Soma (ephedra) was not available it is mentioned in Śatapatha Brāhmaṇa,

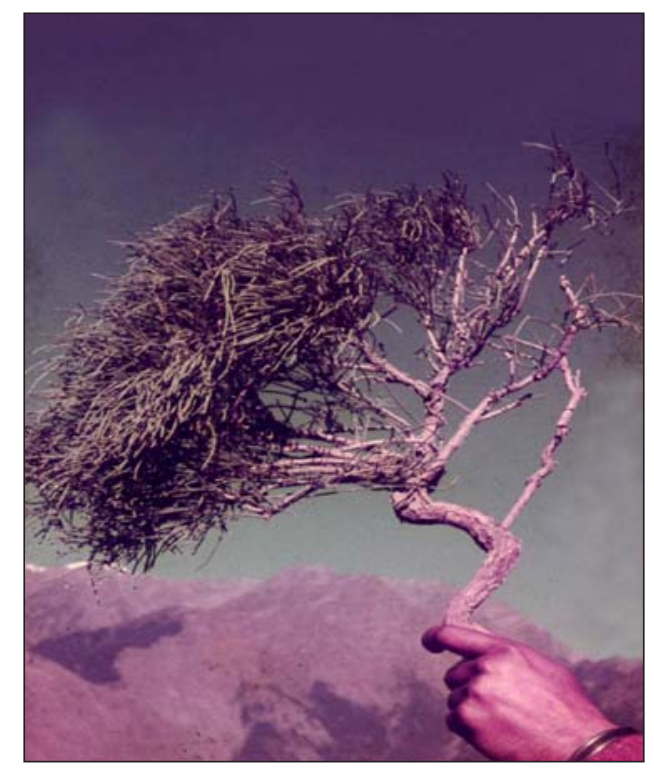

Fig. 8. A twig of ephedra plant collected from Malari (Uttarakhand) by the author in 1982. to use Adar herb and Tāttiriya Brāhmana suggest to use Putica herb. If Putica is not available then to use Arjuna (Terminalia arjuna W\&A). However, Bowman 1970 quoted by Merlin (2013, p.10) stated that in India Brāhmins now use the stalks of $S$. brevistigma under the name 'Pitica' or 'Putica' as Soma. Possibly, the plant was used as a surrogate of Soma in religious worship among the Hindus. However, there is no botanical identification available for Adar.

\section{Classification of the plants used as SUBSTITUTE OR SURROGATES OF SOMA}

The plants so far reported to be used as a substitute and as surrogates of Soma, in India can be classified as (i) psychoactive or hallucinogenic or are strong stimulants; (ii) the plants from which alcoholic drink was prepared by fermentation and (iii) None of these.

\subsection{The Psychoactive or Hallucinogenic Plants}

\subsubsection{Peganum harmala Linn.}

Commonly known as Syrian rue or Harmal. (O’Falttery \& Schwartz 1989) quoted by Damania (2004, p.136,139) and Nene \& Putoo (2004) and Merlin(2013, p.10) have expressed the views that possibly, Peganum harmala L. (Zygophyllaceae), a candidate for Soma in the Iranian homeland due to its hallucinogenic effect. However, b-carboline or harmine, present in the seeds and root, stimulates the brain and induces visual hallucination. It is also known as telepathene for reason of its peculiar ability of contemplation in which the eyes are closed a slight feeling of euphoria is felt. Harmaline was also known as the truth- serum, used by the Germans during Second World War.When, Forte, (1997) asked Wasson about the David Flattery theory of Peganum harmala to be the Soma. In reply Wasson replied, "Oh that is absurd, just absurd. That plant does not lead to a blissful state (Forte, 1997, p. 75) ." 
The plant has also been described by Honinberger (1852, p. 282) from British India under the name of Harmala ruta, and it is stated that the plant is quite common in Lahore like a weed. The seeds are used to fumigate a room with wounded person and for eye-sight weakness and for retention of urine and in spinal pain. But, he did not mention any connection as Soma plant.

\subsubsection{Nymphea Sp. / Nelumbo speciosum (Lotus)}

Recently, Spess, (2000), proposed that the Soma is the Nymphaea and Nelumbo, water lilies and the lotus plants. According to him, "the Nelumbo and Nymphea both have a number of alkaloids and glycosidal compounds with psychoactive properties. These compounds responsible are found in the flowers, sap, nectar, stems, rhizomes, and possibly in the leaves. The flowers of certain Nymphaea species have been shown to induce ecstasy states similar to those of the drug, 3, 4-methylene-dioxymethamphetamine (MDMA), popularly known as "ecstasy". He further states, "India has the largest variety of water lily and lotus plants in the world, and that some of these were known as Soma and called so in Sanskrit texts and stated to be used as Soma due to their psychoactivity."

It is to mention here that Nelumbium with 16 synonyms in Sanskrit(Shastri, 2001, p. 137) and Nymphaea with 27(Shastri, 2001, p. 139) and both are known as Kamal in India. But no name as Soma has been used for it. However, in Rgveda, one hymn (IX.69.5) is on Nymphaea and it is also called as 'Amrta' or (ambrosia) and this name has been given to a number of plants.

According to Sithole (1976, p. 23) the Lotus has long been regarded as a sacred flower of India. Probably, its earlier representation is found at Mohanjo-daro (Harrapan culture ) 25001500 BC. Later, it was represented in Bharut and Sanchi. It has provided the motif or the most varied designs in borders medallions, decorative panels and in Tantrik designs as a tree of life and fortune.
Recently, it has been depicted as an architectural feature in Bahai temple in Delhi and it is also a national flower of India. It is well mentioned in the Hindu and Buddhist mythology and also associated with Lord Vishnu. But, it would be very hard to recognize and accept Nelumbium and Nymphaea as Soma.

\subsection{The Substitutes or surrogates, which yield alcohol on fermentation}

\subsubsection{Sarcostemma spp.}

Roxburgh (1820-24) also mentioned in his book Flora Indica that Asclepias acida (Sarcostemma brevistigma) was used after fermentation in many parts of the peninsula India as Soma. After that a number of scholars had reported the use of Sarcostemma viminale (L.) $\mathrm{R} . \mathrm{Br}$ and S. brevistigma W \&A as Soma.

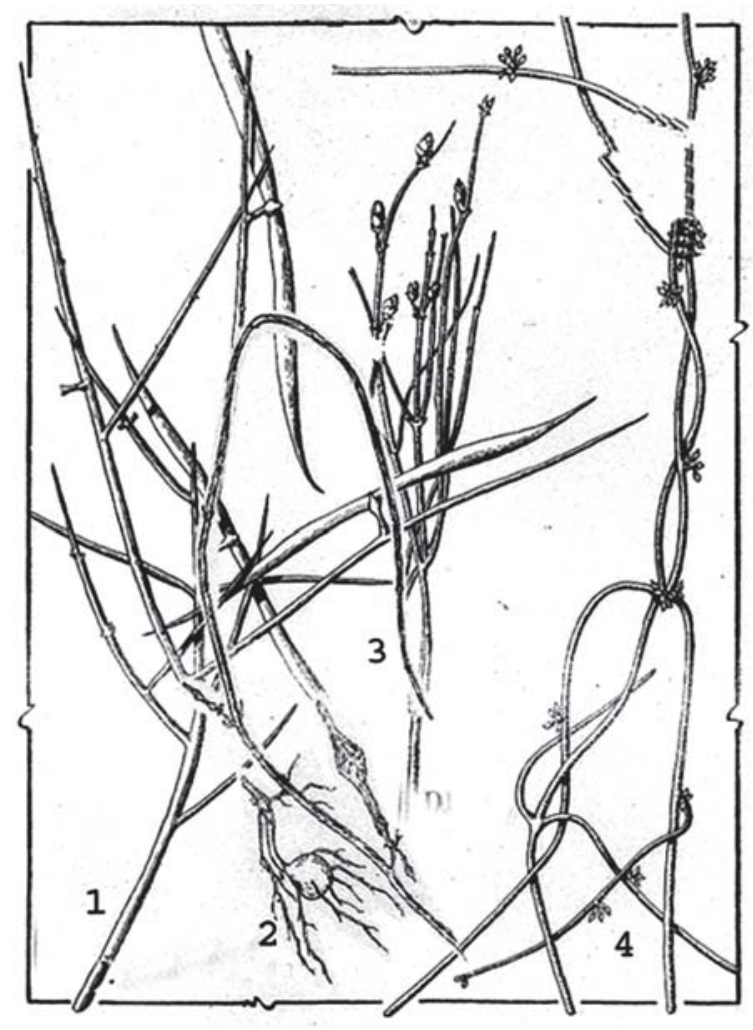

Plate 1. The surrogates and substitutes of 'Soma' used in post-Vedic period in India. Now their use is also lost along with the history of Soma 1. Periploca aphylla 2. Ceropegia juncea 3. Ephedra sp.(used as substitute) and 4.Sarcostemma brevistigma 


\subsubsection{Madhuca indica as Soma in Tamil literature}

In South India, the flowers of Illuppai, Mahua, Madhuca indica, has been identified as Soma (Subramaniam, 1997, p. 15). According to Subramaniam (1997, p. 16), the fruits when pressed to squeeze juice the colour of the juice is described as brown Babhru ruddy, aruna, etc. It a long pedicel called amsu, and actually, he has given the same Rgvedic description as given by Wasson (1968) of Amanita muscaria. The preparation of drink from the fruits after fermentation have been described in detail.

\subsubsection{Ceropegia sp. (Asclepiadaceae)}

Usmanali \& Narayanswami(1970. p. 108) reported Ceropegia juncea being used as Soma by the Ayurvedist in Kerala it is the only botanical species, which has latex, tubers and also distributed in Kerala and also in the Himalayas to fit in with Soma of the characters described in later publications, such as Suśurta Saṃhitā.

\subsection{The substitutes which are neither psychoactive nor yield alcohol on fermentation}

\subsubsection{Ruta graveolens}

When, the hunt of Soma began the first botanist, Willian Roxburgh was in Bengal and he identified the Soma plant as Ruta graveolens in Hortus Bengalensis (Roxburgh 1814) however, no reasons were given, possibly, it was identified due to its vernacular names, Soma or 'Somlatā or the Parsis using it as Soma is not known.’ Furthermore, the plant causes dermatitis. It contains rutin, which restores capillary frigidity (Chopra et al., 1956). It is used in Unani system of medicine in fever, rheumatism, and its essential oil is known as 'Hookworm oil'. It is already been stated that it was used by the Parsis as 'Homa' in Iran (Nene \& Putoo, 2004).

\section{Present status of Soma in Indian Religion \& Culture}

Although, Soma being an important ancient, religious and sacred plant worshipped as a deity, since times immemorial. Presently, it is only mentioned in the hand books of daily or routine worship, used during the religious rites and ceremonies, in each and every house of the Hindus by the Brāhmins or priests right from Kashmir to Kanya Kumari. This handbook is known by different names in different parts of the country. It includes the hymns or mantras from Rgveda (VII.35.1-13). These hymns are in form of a prayer and in these hymns, the deities are remembered, including Soma as a deity and prayed and requested to bestow peace, wealth, happiness, protection to the family of the person, who performs the worship or ' $p \bar{u} j \bar{a}$ '. The hymns are;

$$
\begin{aligned}
& \text { शंनो: सोमो भवतु ब्रह्म शंनः शंनो ग्रावाणः शमु सन्तु } \\
& \text { यज्ञाः। } \\
& \text { शंनः स्वरूणां मितयो भवन्तु शंनः प्रस्व शम्वस्तु वेदिः।। } \\
& \text { (ऋ.वे.मं. } 7 \text { अ. } 35 \text { सू. 7) }
\end{aligned}
$$

शंनो अजएकपाद देवो अस्तु शं नोऽहिर्बुधन्यः शं समुद्रः। शंनोः अपां नपात पेरुरस्तु शंनः पृश्निर्भवतु देवगोपा

(ऋ.वे.मं. 7 अ. 35 सू. 13)

Soma as a God is also remembered in a hymn used in tarpan during Vārcik śrāddhas or śrāddha ceremony, when, every Hindu worships his deceased parents and for fathers. Soma latā, as a plant in practice, is reported to be used in 'Soma yajña' (Sharma, 1998, p. 22). What is botanically somlata $\bar{a}$ is not given. However, in the last 'Soma yajña, which was performed in a big way, about 15-16 yrs ago in the Shanti Kunja, Haridwar and for this the plant, used was Ephedra sp, and it was imported from Pakistan.(This was actually read by the author in a News paper).

\section{Discussion \& Conclusion}

By about 3700 BC the Vedic Āryas possibly used the fly-agaric, a mushrrom, Amanita muscaria to prepare Soma drink. And, when it became rare in nature and was only available at far off distances and on mountains, the Falcons (Syena) birds were used to collect and bring it to their masters. The collection of Soma by the 
Falcons is very well recorded in the Rgvedic hymns. Perhaps, Wasson did not give any importance to this fact, which actually well supports his findings that Soma as the plant like fly-agaric, which is small red and colourful and quite distinguishable and could easily be lifted and brought by the Falcons.

By about 2500-2000 BC, they used ephedra, cannabis and poppy together as Soma.

When they were in the mountainous region they had to use only ephedra, as Soma, which was plentifully available but cannabis and poppy were not available, and, they had completely forgotten even the use of Amanita muscaria as Soma.

In India when they had spread eastwards and southwards in the plains, ephedra was not available so they had to used other plants as substitute and surrogates like: Sarcostemma brevifolia and other Sarcostemma sp., Periplocca aphylla, and Ceropegia sp. etc. on the availability of plants, in different regions, of the country but not as 'Soma'.

The history of Soma plant is perhaps the history of the movement of Vedic Āryas at different periods and places and of plants used according to region and their availability. However, the reasons for their movement, are still to be explored.

\section{ACKNOWLEDGEMENT}

I am thankful to Dr. A.K. Bag, Editor and to Shri Madvendra Narayan, Asst. Executive Director for inviting me to submit this paper for the Golden Jubilee issue of the journal and it is an honour to me. I am further grateful to Dr. S.L. Kapur, ex-Assistant Director of NBRI, Lucknow for going through the text critically and improving it. In last, I would like to pay my tributes to Late Dr. R.V. Sithole, of National Botanic Gardens, Lucknow, who had inspired me about 45 yrs ago to probe into the mystery of Soma plant.

\section{BIBLIOGRAPHY}

Adam Halliday. Let the Falcons Fly. Eye, Sunday Express, Feb, 2-8(2014): 8-13.

Chitampalli, Maruti., Swarga se Prithivi par Soma lanewala pakshi: Shyen, Dharmayug, Feb.9: (1975)19-20 (in Hindi).

Brough, J. Soma and Amanita Muscaria. Bulletin of the School of Oriental and African Studies 34.2 (1971). (Not seen in original).

Chopra, R.N., Chopra, I.C., Handa, K.L. and Kapur, L.D. Indigenous Drugs of India. U.N. Dhurs \& Sons.,1958.

Damania, A.B. The Ancient use of ephedra and tamarix in Zorastrian religious ceremonies, Asian Agri History, 5.3 (2001): 249-257.

Damania, A.B. The Origin of Soma- New theories and Myths., Asian Agri History., 6.2 (2004): 135-139.

O’Flaherty, Wendy Doniger, ed. The Rig Veda, Penguin Book London, England, 1981 (Not seen in original).

Flattery, D.S. and Schwartz, M. Haoma and harmaline- The Botanical identity of the Indo-Iranian Sacred Hallucinogen “soma” and its Legacy in Religion, Language, and Middle Eastern Folklore, Near Eastern Studies.Vol.21. University of California Press, Berkley, USA. (1989): 1-211.

Forte, Robert. A Conversation with R. Gordon Wasson, In Entheogens and the Future of Religion, Ed. Robert Forte). Council on Spritual Practices San Francisco, (1997):.67- 94.

Grotenhermen, Franjo and Russo, Ethan. Cannbis and Cannabinoids pharmacology. Toxicology and therapeutic potential. The Haworth Integrative healing Press. New York. 2002. pp.1-439.

Hillebrandt, A. Vedic Mythology (English Translation of Vedisha Mythologie, 1891 (Reprinted 1980) 2nd revised Ed., Motilal Banarasi Dass, Delhi-PatnaVaranasi.

Honingberger, John Martin. Thirty five years in the East, Bailliere, London. \& R. L. Lepage \& Co. Calcutta. 1852.

Ingalls, Daniel H.H. Remarks on Wasson's Soma. Journal of the American Oriental Society, 91.2 (1971): 188191.

Kak, C.S. On the Chronology of Ancient India, IJHS, 22.3 (1987): 222-234. 
Madanmohan. Bharat mein som ki khoj honi cahiye. Pathako ke patra. Dharmayug 26.1 (1975): 1 (In Hindi).

Mahadihasan, S. Identifying Ephedra as Soma, Pakistan Journal of Forestry October (1963): 370-372.

Mahdihassan, S. Ephedra a Soma meaning hemp fibres with Soma later misidentified as hemp plant itself, IJHS 21.1 (1986): 1-6.

Mahdihassan, S. The Vedic Gods,Agni, Indra and Soma as interrelated: A Study of Soma, IJHS 26.1 (1991): 1115.

Manilal, K.S. An Ethnobotanical connection between Mushrooms and Dolmas. In S.K. Jain(Ed) Glimpses of Indian Ethnobotany, Oxford \& IBH Publishing Co. New Delhi. (1980): 321-326.

Merlin, Mark D. Some aspects of traditional uses of Ephedra species in Eastern Eurasia, Ethnobotany 25.1 (2013): 17.

Monier-Williams, M. A Sanskrit-English Dictionary. Oxford. 1899. Motilal Banarsi Das, New Delhi. (Reprint. 1976).

Mukhoupadhyay, G.M. History of Indian Medicine. University of Calcutta, Calcutta, 1923.

Mukerjee, B.L. The Soma Plant. J. of the Royal Asiatic Soc. Calcutta, 1921-1922. P.241 (Not seen in Original)

Nene, Y.L. Soma, Asian Agri-History 8.3 (2004): 159.

Nene, Y.L. and Putoo, B.L. Soma. Asian Agri-History 8.3 (2004): 159- 160.

Nene, Y.L. and Shadhale Nalini. Agriculture and Biology in Rgveda’. Asian Agri-History 1.3 (2004): 177-190.

Nene, Y.L. and Shadhale Nalini. Origin of Soma. Asian AgriHistory 8.4 (2004): 1247-248.

Padhy, S.N., Dash, S.K. and Mohapatra, R. The Vedic Soma Plant, how much Ethnobotanical ? An Introspective Review, Ethnobotany, 13 (2001): 45-59.

Padhy, S. and Dash, S.K. The Soma Drinker of Ancient India: An Ethno-Botanical Retrospection, J. Hum. Ecol., 15(1) (2004): 19-26.

Qazilvash,N.A. Ephedra of the Rgveda Homa. The Pharmaceutical Journal. 185(1960): 497-501 (Not seen original).

Roxburgh.W. Hortus Bengalensis, Calcutta 1814 (Not seen original).

Roxburgh.W. Flora Indica. Careys Edition, Serampore, Calcutta. 1820-24 (Not seen original).
Sarianidi, Victor. Margiana and Soma-Haoma, Electronic Journal of Vedic Studies, Vol 9.1 May (2003) \& Discovery Channel. http://www.heritageinstitute.com/ zorastrianism/merv/sarianidi.htm

Shastri, Hargovinda. Namlingananusasana or Amarkosa of Amarsinha. Chaukhamba Sanskrit Sansathan, Varanasi.(Sanskri \& Hindi) (2001).

Shastri,Ratnakar. Bharat ke Pranacarya. Atma Ram \& Sons. Delhi. 1977 (In Hindi).

Schultes, R.E. Hallucinogenic plants of the New World. The Harvard Review (Cambride, Mass.) 1.4, Summer (1963): 18-32.

Shah, N.C. Rgveda ka som: Kya bharat mein milta hai ? Dharmayuga. June, (1973): 23-24 (In Hindi).

Shah, N.C. Ephedra: The Ancient herb of India \& China. Herbal Tech Industry.1.8 (2005): 29-32.

Shah, N.C. Building of herbarium at ICMR (CCRAS) Unit at (NBG) NBRI, Lucknows Part XVIII' Herbal Tech Industry. July.5.9 (2010): 25-31.

Shah, N.C. The Mystery and Botanical identity of Soma plant : An Appraisal. XVI 'Herbal Tech Industry. April.8.4 (2011): 18-28.

Shah, N.C. \& Badola, D.P. Som ka Sahitiyak vivechan. Sachitra Ayurveda. Sept. (1977): 207-214 (in Hindi).

Sharma, D.C. Vedon men Dravya gun Shastra (The Science of Medicines in Vedas). Gujarat Ayurveda University, Jamnagar. 1969 (In Hindi).

Sharma, P.V. Original Concept of Soma. IJHS 32.2 (1996): 113-130.

Sharma, Shri Ram. Yaggyon ka gyan Vigyan. Vangmayan 25.4 (1998): 22 (in Hindi).

Sithole, R.V. Plants represented in ancient Indian sculpture. Geophytology. 6.1 (1976): 15-26.

Smith, Huston. Do drugs have religious import ? A thirty five year retrospect. In Thomas B. Roberts (Ed.) Psychoactive Sacramentals. Council on Spiritual Practices, San Francisco, 2001, pp. 1-272.

Spess, David L. Soma : The Divine Hallucinogen. Rochester, Park Street Press, Vermont, 2000 (Not seen in original).

Subramniam,V.I. Tamil Sanskrit interaction in the Agastya Myth. Soma the Illuppai juice. (1979): 1-31.

Swami, BGL. Sources for a History of plant Sciences in India: The Rgvedic Soma plant. Asian Agri-History 14(1): (2010) 7-30. 
Talageri, Shrikant G. The Rgveda. Aditya Prakashan, New Delhi. 2000 http://voiceofdharma.org/books/rig/ img1.jpg

Usman Ali and Narayanswam V. Soma. J. of Research in Ind. Med. 3.1 (1970): 106-110.

Wasson, R.G. Soma: Divine Mushroom of Immortality. Harcourt Brace. \& World, New York. 1968.

Wasson, R.G. The Soma of the Rgveda: What was it ? Journal of the American Oriental Society 91.2 (1971): 169-191.
Wasson, (Rejoinder). Soma and the 'fly-agaric. Botanical Museum of Harvard University, Cambridge. Mass. (1972): 1-58.

Wasson, R.G. and O’Flaherty W. D. The Last Meal of the Buddha. Journal of the American Oriental Society vol. 102.4 (1982): 591-603.

Wilson, H.H. Rgveda Saṃhita. The Bangalore Printing \& Publication Co. Bangalore. 1925.

Yajnik, Prabhulal. Soma: Ek Samalochna. AYU. Oct : (1973)1-16 (In Hindi). 